\title{
Mechanical Crop Load Management (CLM) Improves Fruit Quality and Reduces Fruit Drop and Alternate Bearing in European Plum (Prunus domestica L.)
}

\author{
Sebastian Lammerich ${ }^{1}$, Achim Kunz ${ }^{1}$, Lutz Damerow ${ }^{2}$ and Michael Blanke ${ }^{1, *(1)}$ \\ 1 INRES-Horticultural Science, University of Bonn, D-53121 Bonn, Germany; slammerich@uni-bonn.de (S.L.); \\ akunz@uni-bonn.de (A.K.) \\ 2 Agricultural Engineering Department, University of Bonn, D-53121 Bonn, Germany; damerow@uni-bonn.de \\ * Correspondence: mmblanke@uni-bonn.de; Tel.: +49-228735142
}

Received: 17 July 2020; Accepted: 26 August 2020; Published: 2 September 2020

check for updates

\begin{abstract}
Background: With ca. 10 million tons of annual production worldwide, the plum (Prunus ssp.) ranks as a major fruit crop and can suffer from small fruit size, premature fruit drop and alternate bearing, which are addressed in this paper using a range of crop load management (CLM) tools. (2) Methods: Sixty 10-year-old European plum cv. "Ortenauer" trees on dwarfing St. Julien INRA GF $655 / 2$ rootstock (slender spindle; $4.25 \times 2.80 \mathrm{~m})$ in a commercial orchard near Bonn $\left(50^{\circ} \mathrm{N}\right)$, Germany, were thinned in 2 years and flower intensity assessed in the following year. Thinning was performed either mechanically (type Bonn/Baum) or chemically, with ATS (ammonium thiosulfate) or ethephon (Flordimex), or by a combination of mechanical and chemical methods, to improve fruit quality and the proportion of Class 1 fruit. Adjacent un-thinned trees served as controls. (3) Results: Natural fruit drop in June was reduced from 290 fruits per tree in the un-thinned controls to 265 fruits after ATS blossom treatment, and to 148 fruits after mechanical thinning at $380 \mathrm{rpm}$ at a $5 \mathrm{~km} / \mathrm{h}$ tractor speed at full bloom. The un-thinned control trees developed a large number of small, undersized fruits. The yield of Class 1 fruits increased per tree from $47 \%$ in the un-thinned controls, up to $69 \%$ after crop load management. Sugar content and fruit firmness were unaffected. (4) Conclusions: The study has shown that fruit quality (i.e., fruit size) and financial returns could be improved by either mechanical (380 rpm at $5 \mathrm{~km} / \mathrm{h}$ ) or chemical thinning, or a combination of both.
\end{abstract}

Keywords: European plum (Prunus domestica L.); alternate bearing; crop load management (CLM); fruit drop; fruit quality; mechanical thinning; reducing chemical input; sustainability

\section{Introduction}

With 10 million tons of annual production, plums rank among the major horticultural fruit crops worldwide and in Europe, with cultivation from the Mediterranean island of Skopelos (the "plum island"; $\left.39^{\circ} \mathrm{N}\right)$ to that of the $\mathrm{cv}$. "Opal" plum in Norway $\left(60^{\circ} \mathrm{N}\right)$. The plum is classified as a health-promoting fruit, but the tree is susceptible to alternate bearing, i.e., changes between years, with low ("OFF") or high ("ON") yields.

Crop load management (CLM) and the regulation of fruit set is considerably more difficult in plums compared with that in pome-fruit trees [1,2]. Few chemical thinning agents are effective and registered for stone fruit as a result. While fruits are scarce or absent in "OFF" years, trees in "ON" years are overloaded (Figure 1a), leading to branch breaking (Figure 1b) and an excess of small unmarketable fruits, which are often not picked, if the picking costs exceed the fruit market value. Markets, bakeries and consumers require European plums of large size, and this can be achieved by hand, chemical or mechanical thinning [3]. Plums smaller than $28 \mathrm{~mm}$ cannot be marketed as fresh fruit. Fruits larger 
than $28 \mathrm{~mm}$ qualify as Class 2 fruit, and those larger than $30 \mathrm{~mm}$, as Class 1 (Commission Implementing Regulation (EU) No 543/2011), with the potential for higher financial return. Alternate bearing in European plums can be overcome with blossom thinning [4,5]; however, crop load management (CLM) becomes ineffective later with progressive fruitlet development.

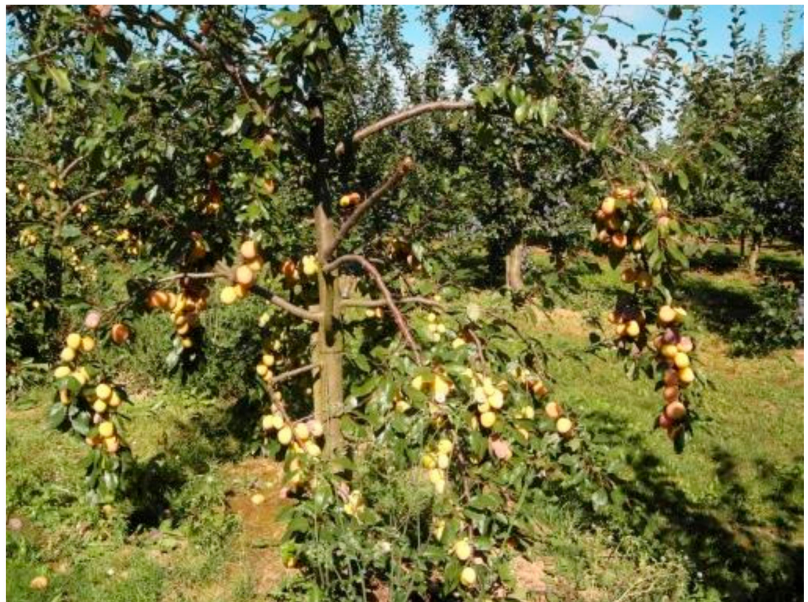

(a)

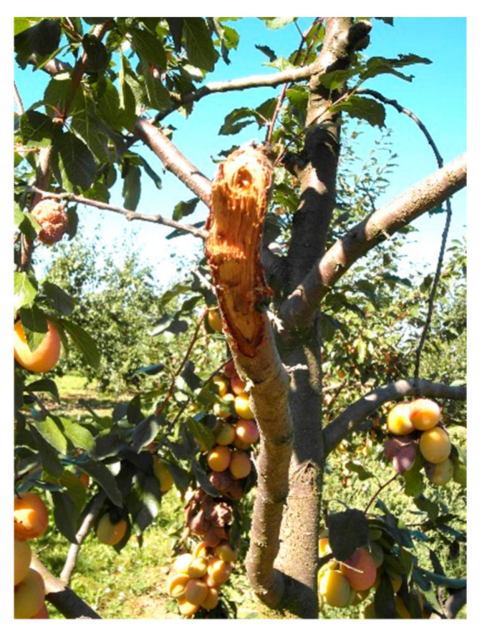

(b)

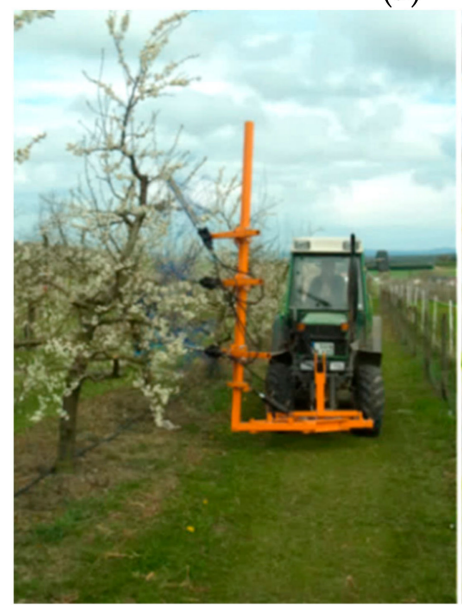

(c)

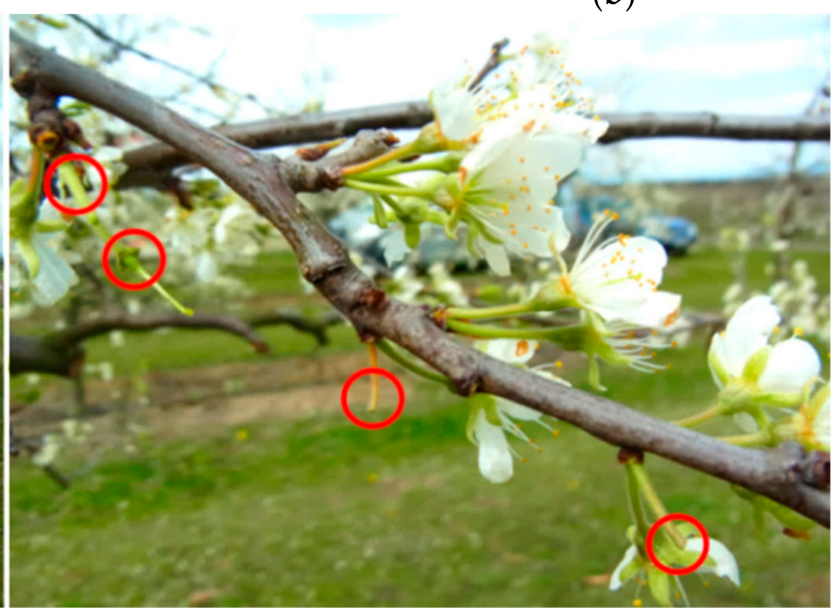

(d)

Figure 1. (a) Overloaded plum tree (top left), (b) which can lead to branch breakage (top right); (c) mechanical thinning in plum cv. "Ortenauer", using the Bonner thinning device ('BAUM') with three rotors and adapted to the spindle tree (bottom left); and (d) individual flowers mechanically removed from the branch (red circles, bottom right) in a commercial orchard near Bonn (Photos (C) M. Blanke, Bonn).

Due to the scarcity, or lack of success of, research on plum thinning, indicated by there being fewer than 10 publications worldwide, the objective of the present study was to apply a range of different CLM mechanisms to improve the fruit quality of the European plum. Field experiments were carried out in a commercial orchard over two years using the latest technology (Figure 1) for mechanical thinning, which was a result of interdisciplinary cooperation between horticulture and engineering, optimized to the needs of previous work [6].

We used this novel technology on its own or in combination with chemical thinning to meet the requirements of each production system—integrated production (IP) and organic — to reduce chemical input into agricultural systems. 


\section{Materials and Methods}

\subsection{Plum Trees}

Sixty ten-year-old plum cv. "Ortenauer" trees, on dwarfing St. Julien INRA GF 655/2 rootstock, were grown in a commercial orchard near Bonn $\left(50^{\circ} \mathrm{N}\right)$, Germany. Trees trained to slender spindles with a spacing of $4.25 \times 2.80 \mathrm{~m}$ in two rows were employed for the trial in the years 2012 and 2013 .

\subsection{Crop Load Management (CLM)}

The plum trees had flowered strongly, with score values of 8-9 on a scale of 0 (no flowers) to 10 (white blossom) after mechanical thinning, in the previous year [6]. The plum trees were either mechanically thinned with the Bonner thinning device (Müller Co., Eltville, Germany) with a rotor speed of $380 \mathrm{rpm}$ at a tractor speed of $5 \mathrm{~km} / \mathrm{h}$ (Figure 1c) at the beginning of full bloom (BBCH 63, F1) in 2012 and on 30 April 2013, or at 320 rpm combined with chemical thinner. The ethylene-releasing compound ethephon (Flordimex at $0.375 \mathrm{~L} / \mathrm{ha}$ ) was applied four weeks after full bloom.

At full bloom, 10 L/ha ATS was applied on 26 April 2012 and 30 April 2013 (Table 1); ATS (ammonium thiosulfate) is a foliar nitrogen fertilizer that can be used at high concentration to interrupt pollen tube growth [7]; adjacent un-thinned plum trees served as controls.

Table 1. Mechanical (green) and chemical (blue) thinning treatments on European plums in 2012 and 2013.

\begin{tabular}{cccc}
\hline Treatment & Magnitude & Date & Flowering Stage \\
\hline & Mechanical treatments (rotor speed) & \\
\hline Mechanical & $380 \mathrm{rpm}$ & $\begin{array}{c}\text { 19 April 2012 } \\
\text { 30 March 2013 }\end{array}$ & Full bloom \\
\hline $\begin{array}{c}\text { Mechanical (and later } \\
\text { chemical) combination }\end{array}$ & $320 \mathrm{rpm}$ & $\begin{array}{l}\text { 19 April 2012 } \\
\text { 30 March 2013 }\end{array}$ & Full bloom \\
\hline ATS & Chemical treatments (concentration) & 4 weeks after full bloom \\
\hline $\begin{array}{c}\text { Flordimex (ethephon) alone } \\
\text { Alordimex (ethephon) (after } \\
\text { mechanical thinning) }\end{array}$ & 10 kg/ha & $\begin{array}{c}\text { May 2012 } \\
\text { May 2013 }\end{array}$ & \\
\hline & \multicolumn{2}{c}{ Control (un-thinned) } \\
\hline
\end{tabular}

\subsection{Fruit Set and Quality Assessment}

Fruit set was determined on 22 May 2012, on 6 June 2013, and after (June) fruit drop on 18 July 2013. Flower clusters were counted on whole trees three days before blossom thinning on each on the trees in the experiment to calculate fruit set. Fruit set was determined after counting the fruitlets on the three largest branches of the trees in the experiment and related to the flower clusters on the respective branch. Fruit quality was assessed using 270 fruits per treatment for firmness measurement (penetrometer), sugar (refractometer type Atago 32) and acidity (titration) on 18 September 2013 as previously described [6].

\subsection{Financial Returns}

Financial returns from the thinning treatments were calculated as the price in Euro cents per kg of fruit, based on the relative proportions of fruit sizes obtained from the wholesale market according to fruit size: $<30 \mathrm{~mm}=4$ cents; $30-32 \mathrm{~mm}=30$ cents $/ \mathrm{kg} ; 32-35 \mathrm{~mm}=40$ cents $/ \mathrm{kg} ;>35 \mathrm{~mm}=60$ cents $/ \mathrm{kg}$.

\subsection{Statistics}

The experiment comprised 60 trees in 2012 and 26 trees in 2013; three branches were employed for the flower-versus-fruit counts per tree, with nine trees per treatment. The data were subjected to statistical analysis using multifactorial analysis of variance in SPSS version 21. 


\section{Results}

\subsection{Fruit Set}

Crop load regulation by mechanical blossom thinning, as an innovative technology, reduced fruit set-Viz., the number of fruit-from 75 plums in 2012 and from 90 plums per 100 flowers in 2013 to 40 fruit in 2012 and to 52 fruit in 2013 after mechanical thinning at $380 \mathrm{rpm}$ (Figure 2). The chemical thinning at full bloom with ATS showed no statistically significant effect on fruit set at this early stage of fruit development.

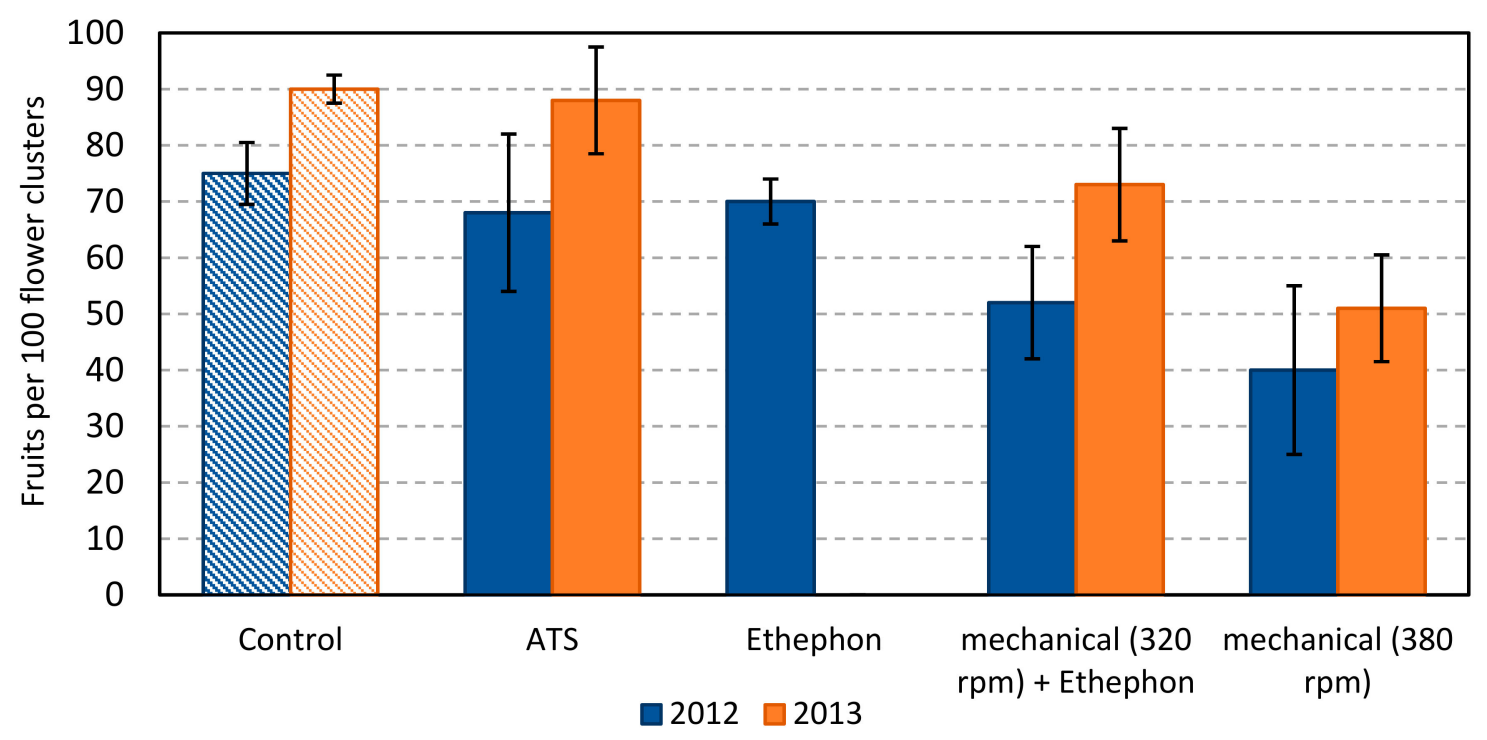

Figure 2. Effect of mechanical crop load management (CLM), chemical CLM and their combination on fruit set in European plum cv. "Ortenauer" in Grafschaft (50N) near Bonn, Germany, in 2012 and 2013, expressed as fruits per 100 flower clusters. Error bars represent SDs at the 5\% level.

\subsection{Fruit Drop}

Since all fruit trees undergo one or several natural fruit drop phases [3], one of the objectives of the present work was to investigate the effect and interaction of crop load management on and with the natural fruit drop of treated European plum trees. Crop load management with mechanical thinning only, at a rotor speed of $380 \mathrm{rpm}$, followed by the combination of $320 \mathrm{rpm}$ at full bloom and ethephon (Flordimex) four weeks later showed the greatest effect in terms of reducing natural fruit drop in European plums (Figure 3). In 2013, the un-thinned plum trees shed 290 fruits per tree, with the largest change of 265 fruits with ATS, and lesser changes of 180 fruits and 150 fruits per tree after mechanical thinning (Figure 3), inversely reflecting the relative magnitude of the thinning motion. The greater the number of fruits removed by the thinning motion, the smaller the number of dropped fruitlets, indicating the good control and promising management of fruit set by crop load management. 


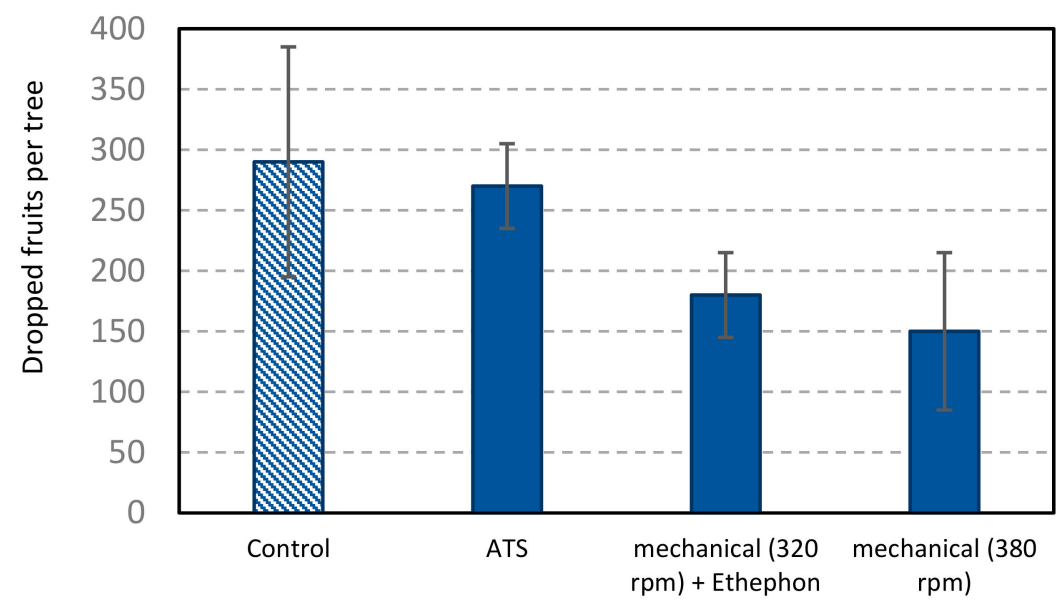

Figure 3. Effect of crop load management (CLM) on fruit drop of the European plum cv. "Ortenauer" in Bonn, Germany, in 2013; error bars represent SDs at the 5\% error level.

\subsection{Fruit Yield}

The success of crop load management is a combination of fruit size, yield and farm gate price; the yields are shown in Figure 4 as the numbers of remaining fruits.

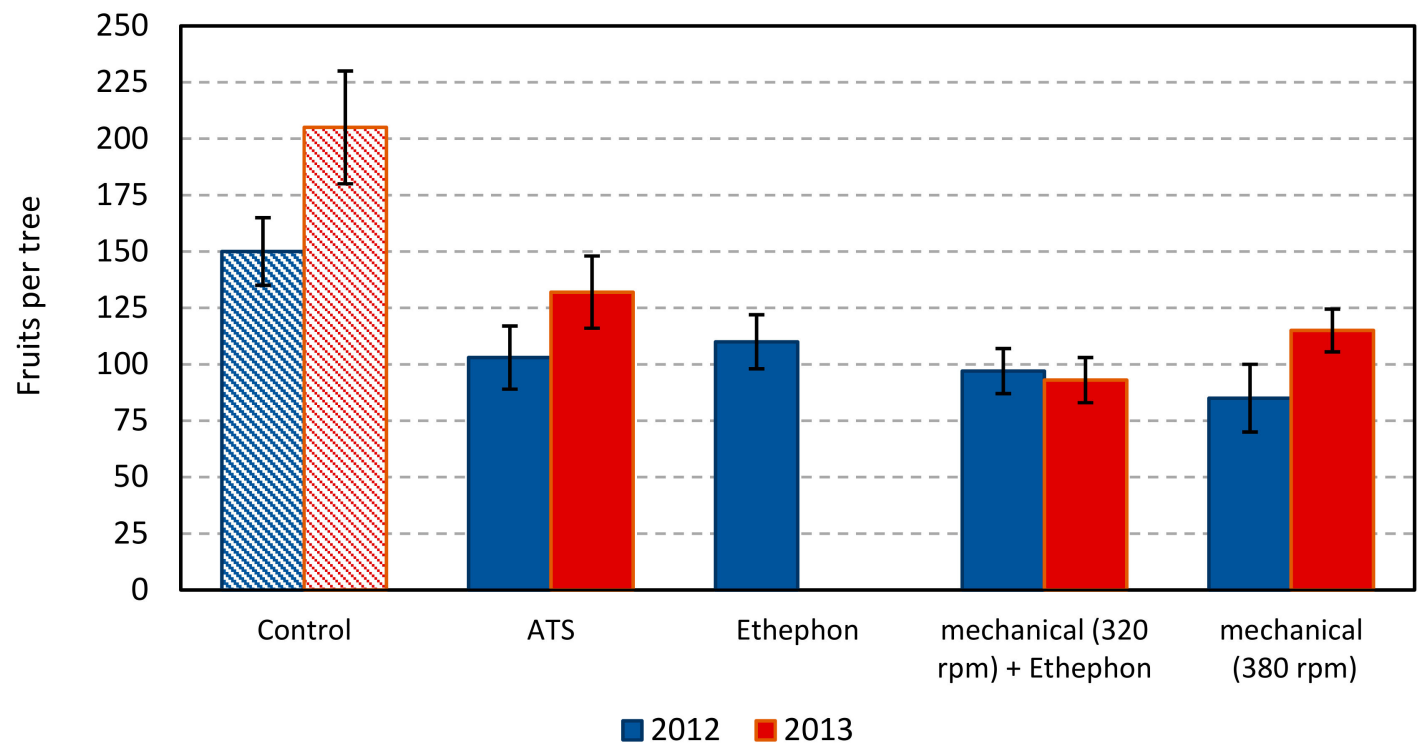

Figure 4. Effect of crop load management (CLM) on yield of the European plum cv. "Ortenauer" in Bonn, Germany, in 2012 and 2013; number of fruit per tree; error bars represent SDs at the 5\% error level.

\subsection{Fruit Quality}

Crop load management (CLM) dramatically reduced the number of small undersized fruits at harvest: from $53 \%$ in the un-thinned control to $41 \%$ after mechanically thinning at $320 \mathrm{rpm}$, and from $34 \%$ at $380 \mathrm{rpm}$ to $31 \%$ with ATS (Figure 5). The sugar content and fruit firmness were not affected by any of the treatments (results not shown). 


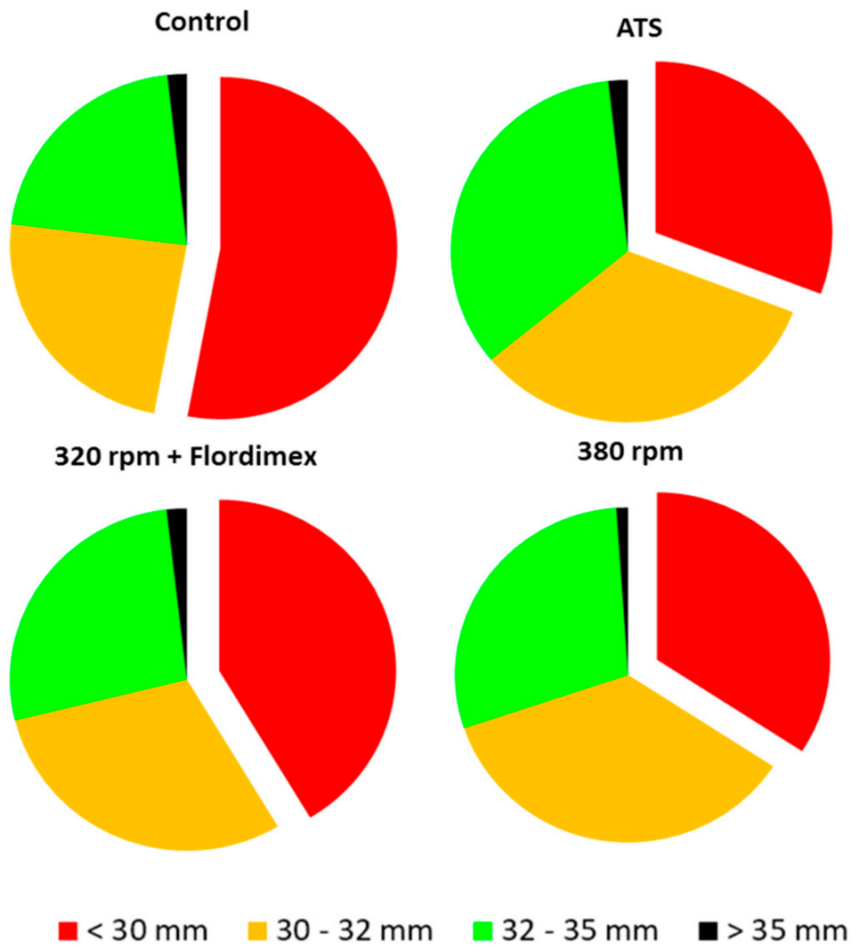

Figure 5. Relative proportions of fruit sizes and quality, as affected by mechanical and chemical thinning, in the European plum cv. "Ortenauer" in Grafschaft in 2013; unmarketable fresh fruit, <30 $\mathrm{mm}$, in red; small, 30-32 mm, in orange; medium-sized fruit, 32-35 mm, in green; and large fruit, >35 $\mathrm{mm}$, in black.

\section{Discussion}

\subsection{Fruit Quality}

The sugar content and fruit firmness were not affected by any of the treatments (results not shown) in contrast to previous findings [3,8-11]. One of the latter studies reported a $0.5 \%$ increase in total soluble solids TSS [12], while Weber [10] reported a tendency toward softer fruits after ethylene (Flordimex) application but-in line with Seehuber [13] and Vandal (1982) [5] —also no difference in sugar content regardless of the thinning treatment. This may be due to blossom thinning with effects on phase I of fruit growth and larger fruit rather than larger sugar/TSS content.

\subsection{Economics}

All the CLM treatments reduced the proportion of undersized, small fruits (Figure 5). The combination of mechanical and chemical thinning (ethephon 30 days after flowering) improved financial returns (to 23 cents per $\mathrm{kg}$ of fruit) relative to the un-thinned control (19 Euro cents per $\mathrm{kg}$ of fruit), based on the proportions of fruit sizes. Chemical thinning with ATS at flowering improved the return to 26 Euro cents per $\mathrm{kg}$ of fruit; mechanical thinning at $380 \mathrm{rpm}$ at flowering improved the return to 24 Euro cents per kg (Figure 6). Manual thinning may improve fruit size, but the required range of 30-90 h/ha may increase labour costs, thereby decreasing the financial returns [11]. With the mechanical thinning (ca. EUR 110/ha), a portion of the labour costs in the order of EUR 300-900/ha/year can be saved, assuming a labour cost of EUR 10/h as in Western Europe. 


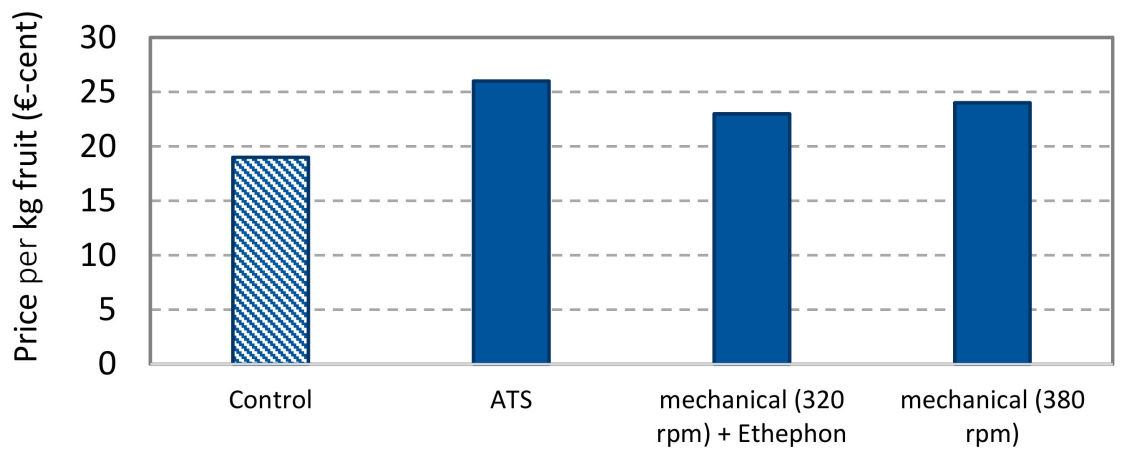

Figure 6. Financial returns from the thinning treatments, expressed as average prices in Euro cent per $\mathrm{kg}$ of fruit and based on the relative proportions of fruit sizes shown in Figure 5, and the following wholesale prices: $<30 \mathrm{~mm}=4$ cents $/ \mathrm{kg} ; 30-32 \mathrm{~mm}=30$ cents $/ \mathrm{kg} ; 32-35 \mathrm{~mm}=40$ cents $/ \mathrm{kg} ;>35 \mathrm{~mm}=60$ cents $/ \mathrm{kg}$.

\subsection{The Sustainability Aspect of Chemical Thinning}

Webster and Andrews (1986) [13] used paclobutrazol (PP333, "Cultar" at 1000 and 2000 ppm) as a one-off application for fruitlet thinning $28 \mathrm{~d}$ after full bloom (AFB; "shuck-off phase"), and the results depended on the cultivar and weather (Table 2), but the compounds failed at full bloom.

Table 2. Features of mechanical thinning.

(1) Reduction of chemical input

(2) Results immediately visible

(3) Weather independent
(4) Improves fruit size and financial return

(5) Prevents over-cropping and branch breakage

(6) Reduction of labour cost for hand thinning
(7) Prevents alternate bearing

(8) Requires spindle trees with flexible horizontal branches

(9) Similar settings can be used for pome and stone fruit

The use of the compound PP333 has now been discontinued in horticultural food production due to residue issues in the soil, tree and fruit, similar to those in the one-off trial with hydrogen cyanamide (Fallahi et al., 1992) [9].

The gibberellin $\mathrm{GA}_{3}$ was used successfully $[2,8]$ to improve fruit size via direct hormonal effects in two consecutive years but not as a thinning agent. In table grapes, for which $\mathrm{GA}_{3}$ is registered and enlarges berry size, partly through pedicel elongation, overdoses may lead to complete yield failure in the subsequent year (Gordon Hoad, 2000, personal communication).

\section{Conclusions}

The results of this three-year field experiment showed that the three crop load managements examined for sustainable plum production can have positive effects on the fruit load and quality of European plums without affecting sugar (TSS) and firmness, improve economic returns to the grower, mitigate alternate bearing in relevant cultivars, prevent the breakage of overloaded branches, and provide healthy fruit every year. The best results were obtained with chemical thinning with a large dose of the foliar fertiliser ATS, or solely mechanical thinning at $380 \mathrm{rpm}$ (Table 2). In the absence of a registration for ATS for thinning, this latter result provides an option for where chemicals are not approved or desired, e.g., if unwanted by consumers or not permitted outside of organic cultivation. Overall, the shortage of chemicals suitable for crop load management in plums necessitates more research.

Author Contributions: Conceptualization and methodology, L.D. and M.B.; investigation, S.L. and A.K.; resources, A.K.; data analysis, S.L.; writing-Original draft preparation, S.L.; writing-Review and editing, L.D. and M.B.; visualization, S.L.; supervision, L.D. and M.B. All authors have read and agreed to the published version of the manuscript. 
Funding: This research received no external funding.

Acknowledgments: We are grateful to Otto Rönn for the repeated access to his private plum orchard in Grafschaft near Bonn and continuous support throughout the experiment by helping to mark the trees and branches, counting fruit on and off the trees, weighing tree yields, taking samples for fruit quality analysis and providing his farm-gate prices for the different fruit categories. We also thank Ligia Hent for editorial guidance, MDPI for the invitation for this contribution to the special features edition of MDPI Horticulturae and waiving the APC.

Conflicts of Interest: The authors declare no conflict of interest.

\section{References}

1. Byers, R.E.; Costa, G.; Vizzotto, G. Flower and fruit thinning of peach and other Prunus species. Hort. Rev. 2003, 28, 351.

2. Meland, M.; Birken, E.M.; Kaiser, C. Managing alternate bearing of "Opal" plum (Prunus domestica L.) trees with $\mathrm{GA}_{3}$ applications by increasing fruit size, and normalizing return bloom and yield in a Nordic climate. In 1st EUFRIN Thinning Working Group Symposia; Blanke, M.M., Costa, G., Eds.; Acta Horticulturae: Leuven, Belgium, 2013; Volume 998, pp. 61-66.

3. Costa, G.; Blanke, M.M.; Widmer, A. Principles of thinning in fruit tree crops-Needs and novelties. In 1st EUFRIN Thinning Working Group Symposia; Blanke, M.M., Costa, G., Eds.; Acta Horticulturae: Leuven, Belgium, 2012; Volume 998, pp. 17-26.

4. Maage, F. Fruit development of 'Victoria' plums in relation to leaf number. Acta Hortic. 1994, 359, $190-194$. [CrossRef]

5. Vangdal, E. Sugars and sugar alcohols in Norwegian grown plums. Meldinger fra Norges Lankbrukshoegskole $1982,61,1-39$.

6. Seehuber, C.; Kunz, A.; Damerow, L.; Blanke, M.M. Regulation of source: Sink relationship, fruit set, fruit growth and fruit quality in European plum (Prunus domestica L.)-Using thinning for crop load management. Plant Growth Regul. 2011, 65, 335-341. [CrossRef]

7. Maas, F. Control of fruit set in apple requires careful timing of ATS application. In 2nd EUFRIN Thinning Working Group Symposia; Acta Horticulturae: Leuven, Belgium, 2016; Volume 1138, pp. 45-52.

8. Boyham, G.E.; Norton, J.B.; Abraham, B.R.; Pitts, J.A. GA 3 and thinning affect fruit quality and yield of 'Au-Rubrum' plum. HortScience 1992, 27, 1045. [CrossRef]

9. Fallahi, E.; Simons, B.R.; Fellman, J.K.; Colt, W.M. The use of hydrogen cyanamide in apple and plum thinning. Plant Growth Regul. 1992, 11, 435-439. [CrossRef]

10. Weber, H.J. Chemical and mechanical thinning of plums. In 1st EUFRIN Thinning Working Group Symposia; Blanke, M.M., Costa, G., Eds.; Acta Horticulturae: Leuven, Belgium, 2013; Volume 998, pp. 51-60.

11. Walsh, K.B.; Long, R.L.; Middleton, S.G. Use of near infra-red spectroscopy in evaluation of source-sink manipulation to increase the soluble sugar content of stonefruit. J. Hort. Sci. Biotechn. 2007, 82, 316-322. [CrossRef]

12. Seehuber, C.; Damerow, L.; Blanke, M.M. Effect of mechanical thinning on source: Sink relationship, fruit quality and yield in plum [Einfluss von mechanischer Fruchtbehangsregulierung auf die Source: Sink-Verhältnisse, Fruchtqualität und Ertrag von Pflaumen.]. Erwerbs-Obstbau 2012, 54, 1-9. [CrossRef]

13. Webster, A.; Andrews, L. Flower and fruit thinning of 'Victoria' plums (Prunus domestica L.) with paclobutrazol. In V International Symposium on Growth Regulators in Fruit Production; Acta Horticulturae: Leuven, Belgium, 1986; Volume 179, pp. 703-704.

(C) 2020 by the authors. Licensee MDPI, Basel, Switzerland. This article is an open access article distributed under the terms and conditions of the Creative Commons Attribution (CC BY) license (http://creativecommons.org/licenses/by/4.0/). 